\author{
Anna Dolata-Zaród \\ Opole
}

\title{
ASPEKTY KULTUROWE W TŁUMACZENIU TEKSTÓW SPECJALISTYCZNYCH
}

\footnotetext{
Zarys treści: Rola tłumacza polega na pośredniczeniu między odmiennymi kulturami i językami. Dobrego tłumacza winna zatem cechować kompetencja przedmiotowa (treściowa), językowa i kulturowa. W niniejszym artykule spróbujemy odpowiedzieć na pytanie, jaka jest rola aspektów kulturowych w tłumaczeniu tekstów specjalistycznych, na przykładzie francuskiego języka prawa. W tym celu postaramy się zdefiniować pojęcie „elementów kulturowych”, a nastepnie przeanalizujemy kilka wybranych przykładów z różnych dziedzin prawa.
}

T łumaczenie jako zabieg polegający na oddaniu w innym języku tego, co zawiera tekst w języku wyjściowym, jest niewątpliwie operacją trudną i wymagającą odpowiednich kompetencji. Jednym z podstawowych rodzajów tłumaczeń obok przekładu literackiego jest tłumaczenie specjalistyczne. Według Bermana (1984) „teksty specjalistyczne to takie, których podstawowym zadaniem jest przekazanie podstawowych informacji” (Dąmbska-Prokop 2000: 255). Tak więc zajmując się tłumaczeniem tekstów specjalistycznych, należy się kierować przede wszystkim zasadą komunikatywności. Berman (1984) formułuje trzy najważniejsze reguły, którymi powinniśmy się kierować w tłumaczeniu tekstów specjalistycznych:

1) informacje mają być przekazane w sposób jasny, odpowiedzialny i skuteczny,

2) mając na uwadze fakt, że tekst wyjściowy jest przeznaczony dla określonych odbiorców, tekst docelowy musimy także dostosować do nowych, określonego typu odbiorców,

3) aby przekład mógł spełniać swoją rolę, tj. przekazywać informację 
w sposób zrozumiały, musi uwzględniać realia kulturowe języka docelowego (por. Dąmbska-Prokop 2000: 225-226).

Tłumaczenia tego typu wymagają odpowiednich kompetencji: przedmiotowych, językowych i kulturoznawczych. Zabieg ten nastręcza szczególnych trudności, wynikających z odmienności elementów kulturowych krajów języków przekładu. Należy w tym miejscu wspomnieć, że D. Lachowicz słusznie twierdził, iż „wypowiedzi pozbawione kontekstu społeczno-kulturowego mogą być poprawne konstrukcyjnie, ale nieodpowiednie pod względem wymogów sytuacyjnych" (1977: 141).

Pod pojęciem „elementy kulturowe” rozumiemy takie elementy tekstu, które w sposób szczególny łączą się z kulturą danego kraju. Tak określane elementy kulturowe obejmują większość imion własnych, nazwy i zwroty związane $\mathrm{z}$ organizacją życia $\mathrm{w}$ kraju kultury wyjściowej, obyczajami i przyzwyczajeniami, cytaty i aluzje mające ścisły związek z literaturą danego kraju, aluzje do jego historii i do innych sfer kultury, takich jak muzyka, film, malarstwo itd. (por. Hejwowski 2004: 71-72). Mnogość tego typu różnic kulturowych, które często trudno wytłumaczyć obcokrajowcom, przy próbie przekładu sprawia, że niektórzy teoretycy piszą o „obcości w przekładzie” (Lewicki 2002: 43-52). Dochodzi się więc do wniosku, że w przypadku elementów kulturowych nie należy oczekiwać od odbiorców przekładu podobnej reakcji, gdyż to, co jest dobrze znane i swojskie dla odbiorców oryginału, będzie obce, a czasem wręcz egzotyczne dla odbiorców przekładu (Hejwowski 2004: 72). $\mathrm{Z}$ całą pewnością odbiorcy tekstów silnie nacechowanych kulturowo nie zrozumieją wszystkiego, jednakże jest to także zależne od wiedzy odbiorcy. Nawet rodzimy odbiorca nie zrozumie tekstów literackich bądź prawniczych bez odpowiedniej wiedzy.

Tłumacz jako uczestnik i mediator jest częścią kultury. W procesie komunikacji pełni on funkcję interpretatora symboli, znaków i kodów kulturowych. Aleksander Kamiński określa kulturę jako „zespół wartości (intelektualnych, estetycznych, społecznych, gospodarczych itp.), norm (moralnych, prawnych itp.) oraz wzorów i wzorców (zachowań, instytucji etc.), które pragniemy propagować i do których chcemy wprowadzić jednostki i grupy społeczne przez wzmaganie i budzenie odpowiednich zainteresowań i potrzeb" (1974: 57). W kulturach pozostających w bliskim kontakcie, czy to dzięki wymianie gospodarczej, wzajemnym długotrwałym kontaktom, czy po prostu sąsiedztwie geograficznym, wzajemna świadomość symboli i wartości kulturowych zawartych w pojęciach, wyobrażeniach, obrazach, strukturach gramatycznych lub tekstach może być bardzo wysoka. Odległość kulturowa pogłębia różnice pojęciowe i może utrudniać rozpoznawanie wartości kulturowych, 
tworząc również bariery przekładowe. Zdzisław Aleksander podkreśla, że ,język jako twór społeczny jest nieodłączną częścią cywilizacji i kultury danego społeczeństwa. Odzwierciedlają się w nim różnice w sposobie widzenia rzeczywistości pozajęzykowej, a także wzorce i normy zachowania" (1982: 5). Granice przekładalności w tłumaczeniu elementów kulturowych opierają się na świadomości i doświadczeniu kulturowym odbiorcy. Gdy interpretujemy inną kulturę, opieramy się na własnych wzorcach kulturowych, zwyczajach i rutynach, nakładając coś $\mathrm{w}$ rodzaju filtru kultury docelowej na nasz indywidualny filtr percepcyjny - jak podaje Hejwowski (2004: 76), „tłumacz przekłada własną interpretację kulturowych implikacji wynikających z oryginału. Stopień udomowienia na gruncie docelowym elementów kulturowych jest decyzją strategiczną tłumacza i musi wypływać ze świadomości istoty nieprzetłumaczalności w danym przypadku". Rabczuk dodaje w tym kontekście, że „charakter wielokulturowy współczesnych społeczeństw europejskich jest [...] wynikiem procesu globalizacji: przenikania się modeli kulturowych, ideałów oraz wartości dzięki postępowi i głębokim zmianom w technikach komunikacji, gromadzeniu i przetwarzaniu danych" (2002: 19-20). Zatem różnice w obyczajach, wierzeniach, poglądach, instytucjach prawnych i państwowych społeczeństw europejskich sprawiają, że przy tłumaczeniu tekstów należy zastosować odpowiednie strategie translatorskie i szukać odpowiednich rozwiązań.

Język prawa jest szczególnym systemem językowym, który jest przykładem istnienia zbioru słownictwa specjalistycznego niedającego się tak łatwo przetłumaczyć. W tłumaczeniu z zakresu prawa używa się często ekwiwalencji, która pozwala na zastąpienie danego terminu innym istniejącym w języku docelowym, który niekoniecznie musi być równoznaczny z tym pierwszym (częste zastosowanie w nazwach instytucji). Według J. Pieńkosa można wyróżnić trzy typy terminów prawniczych. Pierwsze to te, które mają swój odpowiednik semantyczny w języku obcym (offre - 'oferta'), następnie te, dla których używa się odpowiednika funkcjonalnego, oraz te, które można uważać za nieprzekładalne (common law - nieprzetłumaczalne na język francuski ani na żaden inny język) (2003: 99).

$\mathrm{Na}$ obszarze prawa, gdzie powinna panować pełna niemal jednoznaczność terminów, występuje niesłychanie często wieloznaczność terminologiczna (droit personnel - 'prawo osobiste', ale też 'prawo osobowe'). Problemy ze słownictwem prawniczym mają swoje źródło w różnych poglądach na prawo, w istnieniu różnych instytucji oraz $\mathrm{w}$ fakcie, że system prawny, tak jak język, ulega pewnym modyfikacjom. Ważne jest zatem, aby tłumacz miał odpowiednią wiedzę specjalistyczną, aby swobodnie mógł poruszać się w danej dziedzinie. 
Na poziomie treściowym języka prawa rozpatruje się zarówno informacje niezdeterminowane socjokulturowo, czyli uniwersalne, i zdeterminowane socjokulturowo. Do pierwszych zalicza się prawa i formuły obowiązujące w każdym języku i wspólnocie kulturowej, natomiast do drugich należą te, które istotne są tylko w określonych kręgach kulturowych (por. Troszczyńska-Nakonieczna 2003: 257). Należy tu więc wspomnieć, że każdy system prawny jest niezależny, samowystarczalny i ma wyraźnie zakreślone granice. Kiedy mówimy natomiast o współistnieniu systemów prawnych, należy brać pod uwagę relacyjność elementów, istotną rolę prawa międzynarodowego i wspólne źródła. Zatem zarysowuje się tutaj relacja między systemem inter- i intrakulturowym.

Na płaszczyźnie kulturowej mamy do czynienia z cechami zakorzenionymi w realiach kulturowych danej społeczności. Znajomość owych aspektów kulturowych, społecznych i politycznych kraju, z którego pochodzi tłumaczony tekst, warunkuje jego właściwy przekład; oznacza to, że translat jest zrozumiały i merytorycznie poprawny. W przypadku tekstów prawniczych brak tego typu wiedzy i odpowiednich kompetencji może przynieść poważne szkody. Jako przykład niech posłuży nam tłumaczenie francuskich instytucji prawniczych. Podejmując się tego zadania, należy bezwzględnie korzystać $\mathrm{z}$ aktów prawnych francuskich i polskich w celu znalezienia właściwych ekwiwalentów. Aby dokonać dobrego tłumaczenia tekstu prawniczego lub prawnego, trzeba dysponować rozległą wiedzą dotyczącą znajomości systemów prawnych obu języków, jak również podłoża historycznego powstawania prawa. Bez uwzględnienia tej specyfiki niemożliwe staje się przetłumaczenie choćby nazewnictwa sądów czy ciągu instancji administracyjnych.

Barbara Kielar (2000: 235) pisze, że tekst przekładu powinien być w stosunku do oryginału ekwiwalentny co do treści i/lub formy, mimo różnic między konwencjami obu języków i towarzyszącemu każdemu z nich tłu kulturowemu. Tak więc zajmując się tłumaczeniem tekstów specjalistycznych, należy mieć na uwadze wszelkiego typu różnice kulturowe. Jedną z nich jest sposób tłumaczenia nazw stanowisk, które na przykład zajmują przedstawiciele organizacji międzynarodowych, nazwy działów współpracy międzynarodowej oraz innych organów. W języku francukim są one pisane małą literą bądź tylko pierwszy człon całej nazwy jest pisany wielką literą:

Artykuł 27d

Nie naruszając uprawnień Urzędu Przewodniczącego i Komisji, Sekretarz Generalny Rady i Wysoki Przedstawiciel do spraw Wspólnej Polityki Zagranicznej i Bezpieczeństwa czuwa w szczególności, aby Parlament Euro- 
pejski i wszyscy członkowie Rady zostali w pełnym zakresie poinformowani o realizacji każdej ściślejszej współpracy w dziedzinie Wspólnej Polityki Zagranicznej i Bezpieczeństwa.

\section{Article 27D}

Sans préjudice des compétences de la présidence et de le Commission, la secrétaire général du Conseil, haut représentant pour la politique étrangère et de sécurité commune, veille en particulier à ce que le Parlement européen et tous les membres du Conseil soient pleinement informés de la mise en oeuvre des coopérations renforcées dans le domaine de la politique étrangère et de sécurité commune. (Traktat z Nicei. Treaty of Nice. Traité de Nice. Vertrag von Nizza 2001: 37, 39)

Tłumaczenie nazwy présidence obecnej w artykule ustawy i przetłumaczonej na język polski jako Urząd Przewodniczącego stanowi przykład zastosowania przez tłumacza techniki rozwinięcia definicyjnego, do której wrócę w dalszej częsci pracy. Poza tym w przytoczonych fragmentach zauważyć można różnicę w sposobie zapisywania w poszczególnych językach oznaczeń artykułów. W języku francuskim litery określające poszczególne części artykułów są zapisywane wielką literą albo nawet słownie: Artykuł 32c-Article 32 quater (Traktat z Nicei. Treaty of Nice. Traité de Nice. Vertrag von Nizza 2001: 213, 215).

Wobec braku odpowiednich znaków językowych i elementów leksykalnych, którymi można by opisać rzeczywistość pozajęzykową, zasadniczym problemem jest to, jak stworzyć przekład możliwie najbardziej wierny. Z tego względu tłumacze posługują się takimi technikami, jak: opuszczenie, bezpośredni transfer, rozwinięcie definicyjne czy ekwiwalencja (por. Tomaszkiewicz 2006: 155-165).

Tłumaczenie nazw administracyjnych czy też nazw własnych, które dla odbiorcy tekstów docelowych może nie być oczywiste, wymaga często zastosowania tzw. rozwinięcia definicyjnego. Ma ono miejsce wówczas, gdy stosujemy opis dango terminu, który znajduje się w tekście wyjściowym, a który nie ma odpowiednika w języku docelowym. Często jest on stosowany w formie przypisu lub komentarza.

[...] w 1989 r. Conseil d'Etat (organ, który nie ma polskiego odpowiednika, byłby nim urząd łączący kompetencje naszej Rady Legislacyjnej i Naczelnego Sadu Administracyjnego) wydał orzeczenie. (Graczyk 2003) 
Des Relations avec le Parlement: il refuse. De la Culture: il refuse. (Le Figaro 07.05.2007)

[...] odrzuca też tekę ministra ds. Kontaktów z Parlamentem. I ministertwo kultury. (Forum nr 20)

Do tego typu rozwinięcia można też zakwalifikować zabieg, który polega na pozostawieniu jednego elementu danego zwrotu:

Le statut peut prévoir que le Tribunal est assisté d’avocats généraux.

W statucie może być przewidziane, że Sąd Pierwszej Instancji wspierany jest przez Rzeczników Generalnych. (Traktat z Nicei. Treaty of Nice. Traité de Nice. Vertrag von Nizza 2001: 213,215)

Przekład tekstów prawnych i prawniczych stwarza nie tylko trudności w sensie technicznym i językowym, ale przede wszystkim interpretacyjnym. Aby trafnie przetłumaczyć dany tekst, tłumacz musi przede wszystkim zrozumieć komunikat, dlatego też powinien posiadać on mieć wiedzę o systemie prawnym języka docelowego. Nie można bowiem przekładać norm prawnych na język obcy, nie uwzględniając faktu, że zostały one opracowane dla i przez innych odbiorców żyjących w odmiennych warunkach społecznych, politycznych, kulturowych czy prawnych. Ponadto należy zawsze odwoływać się do tekstów źródłowych, aby terminologia przekładu była - o ile to możliwe kompatybilna z językiem wyjściowym. Jako przykład niech posłuży tu regulacja prawna przelewu wierzytelności w prawie polskim i francuskim. Artykuł 1691 kodeksu francuskiego mówi:

Si, avant que le cédant ou le cessionnaire eût signifié le transport au débiteur, celui-ci avait payé le cédant, il sera valablement libéré.

Natomiast w artykule 512 polskiego kodeksu znajdujemy:

Dopóki zbywca nie zawiadomił dłużnika o przelewie, spełnienie świadczenia do rąk poprzedniego wierzyciela ma skutek względem nabywcy.

Jak widać z powyższego, w uregulowaniach francuskich stronami umowy przelewu wierzytelności są le cédent (cedent) i le cessionnaire (cesjonariusz), podczas gdy ustawodawca polski używa terminów zbywca i nabywca. Fakt ten jest dość zadziwiający, zwłaszcza jeśli weźmiemy pod uwagę, że terminy 
cedent i cesjonariusz są powszechnie używane zarówno przez doktrynę prawa cywilnego, jak i orzecznictwo oraz prawników polskich.

W procesie tłumaczenia tekstów prawnych i prawniczych istotną rolę odgrywa problem kalk językowych. Jest to ważne $z$ powodów terminologicznych i merytorycznych. Przywołajmy więc jeden z przepisów Konstytucji Europejskiej i jego pierwotną wersję tłumaczenia w jezyku polskim:

Artykuł I-39, akapit 2, ustęp 2:

Les règlements européens et les décisions européennes, lorsqu'elles n'indiquent pas de destinataire, sont publiés au Journal officiel de l'Union européenne et entrent en vigueur à la date qu'ils fixent ou, à défaut, le vingtième jour suivant leur publication. (www.constitution-européenne.fr)

Łeżeli rozporządzenia europejskie i decyzje europejskie nie wskazują adresata, są one publikowane w Dzienniku Urzędowym Unii Europejskiej i wchodzą w życie z dniem w nich określonym lub, w jego braku, dwudziestego dnia po ich opublikowaniu. (www.constitution-européenne.fr)

Na podstawie przytoczonego przykładu można zauważyć, że zaproponowane tłumaczenie zmienia sens pojęcia normy prawnej, gdyż ustawodawcy chodziło wyłącznie o decyzje europejskie, które nie wskazują adresata, a nie o decyzje i rozporządzenia jednocześnie. Zresztą jeżeli przeanalizujemy gramatycznie wspomniany przykład, to z łatwością dojdziemy do wniosku, że przepis ten odnosi się do słowa decyzje, gdyż w wersji francuskiej mamy użyty zaimek elles, właściwy dla rodzaju żeńskiego liczby mnogiej. Rzeczownik règlements występuje natomiast w rodzaju męskim liczby mnogiej. Zatem bez wątpienia wspomniany przepis należy przetłumaczyć jako

Rozporządzenia europejskie oraz niewskazujące adresata decyzje europejskie są publikowane w Dzienniku Urzędowym Unii Europejskiej i wchodzą w życie z dniem w nich określonym lub, w jego braku, dwudziestego dnia po ich opublikowaniu. (www.constitution-européenne.fr)

Przekład specjalistyczny nie jest prostą operacją polegającą na bezpośredniej zamianie słów na ich odpowiedniki w obcym języku. Szczególnie przekład tekstów prawniczych, ze względu na to, jak złożoną dziedziną jest prawo, przysparza wiele trudności, nie tylko technicznych, ale także interpretacyjnych. Dodatkowo transfer kulturowy pogłębia ten problem. Aby osiągnąć poziom gwarantujący rzetelny przekład tekstów specjalistycznych, konieczne są wiedza i długoletnie doświadczenie. Reasumując, nie można dokonać dobre- 
go tłumaczenia tekstu specjalistycznego bez wniknięcia w jego aspekty kulturowe. Oprócz wiedzy językowej i merytorycznej konieczna jest także znajomość kultury danej dziedziny, które to czynniki warunkują odpowiednie tłumaczenie. W przypadku języka prawa ma to znaczenie tym bardziej istotne, że poszczególne systemy prawne różnią się znacząco, a przekład ma być zrozumiały dla potencjalnego odbiorcy nieznającego realiów życia w innym kraju.

\section{Literatura}

Berman, A., 1984, Lépreuve de l'étranger, Paris.

Aleksander, Z., 1982, Elementy lingworealioznawcze w nauczaniu języka rosyjskiego, Warszawa.

Code civil des Français 2004, Lédition du Bicentenaire, LexisNexis Litec.

Czachórski, W., 1999, Zobowiazania. Zarys wykładu, Warszawa.

Dąmbska-Prokop, U. (red.), 2000, Mała encyklopedia przekładoznawstwa, Częstochowa.

Filipiak, M., 2000, Socjologia kultury. Zarys zagadnień, Lublin.

Graczyk, R., 2003, „Meczet i katedra”, Polityka, nr 50.

Hejwowski, K., 2004, Kognitywno-komunikacyjna teoria przekładu, Warszawa.

Kamiński, A., 1974, Funkcje pedagogiki społecznej, Warszawa.

Kielar, B.Z., 2000, „O tłumaczeniu tekstów specjalistycznych”, [w:] Problemy komunikacji międzykulturowej. Lingwistyka, translatoryka, glottodydakty$k a$, Kielar, B.Z. i in. (red.), Warszawa, s. 235-246.

Lachowicz, D., 1977, „Komunikacja językowa a kontekst społeczno-kulturowy", [w:] Języki Obce w Szkole, nr 3, s. 141.

Ladmiral, J.-P., 1979, Traduire: théorèmes pour la traduction, Paris.

Lewicki, R., 2002, „Obcość w przekładzie a obcość w kulturze”, [w:] Przekład-język-kultura, Lewicki, R. (red.), Lublin, s. 43-52.

Mounin, G., 1963, Les problèmes théoriques de la traduction, Paris.

Pieńkos, J., 1999, Podstawy juryslingwistyki. Język w prawie - Prawo $w$ języ$k u$, Warszawa.

Pieńkos, J., 2003, Podstawy przekładoznawstwa. Od teorii do praktyki, Kraków.

Skibińska, E., 1999, Przekład a kultura. Elementy kulturowe we francuskich tłumaczeniach „Pana Tadeusza”, Wrocław.

Szymczak, M. (red.), 1998, Słownik języka polskiego, Warszawa.

Tomaszkiewicz, T., 2003, Terminologia tłumaczenia, Poznań. 
Tomaszkiewicz, T., 2006, Przekład audiowizualny, Warszawa.

Traktat z Nicei. Treaty of Nice. Traité de Nice. Vertrag von Nizza, 2001, [w:]

Przepisy Europejskie, Bielsko-Biała.

Troszczyńska-Nakonieczna, W., 2003, „Pragmatyczne aspekty badań gatun-

ków tekstów specjalistycznych na potrzeby tłumaczeń i dydaktyki”, [w:]

Języki specjalistyczne. Zagadnienia dydaktyki i przekładu, Mamet, P. (red.),

Katowice, s. 247-259.

Wojtasiewicz, O., 1957, Wstęp do teorii tłumaczenia, Warszawa.

http://www.europarl.europa.eu

http://www.constitution-européenne.fr

\section{Cultural aspects in translation of specialist texts}

\section{Summary}

Different views on law, the existence of a variety of institutions and the fact that the legal system, similarly to language, is being constantly modified bring about problems with legal vocabulary. It is therefore crucial that the translators have proper specialist knowledge in order to be well acquainted with a given field. Legal and law texts are not only difficult to translate in technical and language terms, but they are, first of all, difficult to interpret.

A correct and accurate translation of a given text requires that a translator is knowledgeable about the legal system of the target language. No legal norms can be translated into a foreign language without taking into consideration the fact that they have been prepared by and for other people living in different social and political conditions, where different cultural and legal rules are observed.

To sum up, a careful study of cultural aspects is essential if a good translation of a specialist text is to be made. Thus, a professional translator not only has to master the target language but s/he also has to be familiar with the substance and culture of a given field. In case of legal language and the language of law the above is even more important since particular legal systems are significantly different and the translation has to be intelligible to a potential receiver who is not acquainted with the reality of a given country.

The present article attempts at answering the question about the role of cultural aspects in translation of specialist texts as exemplified by the French legal system. The notion of "cultural elements" is defined and several examples chosen from different fields of law are analyzed to achieve the above aim. 